\title{
EPISTEMOLOGI ILMU-ILMU TASAWUF
}

\author{
Ahmad \\ Dosen mata kuliah Akhlak Tasawuf \\ Fakultas Ushuluddin dan Humaniora IAIN Antasari Banjarmasin \\ Diterima tanggal 5 November 2014 / Disetujui tanggal 4 Desember 2014
}

\begin{abstract}
As all religions have their mysticism, Islamic mysticism is well known as Sufism. In its development, many schools of Sufism appeared and they had been influenced by several religions and beliefs around such as Christian, Buddhism, Hinduism, Gnotisism, etc. This article tends to tell about Islamic Mysticism and its epistemology. It will be discussed about the definition of Sufism, its schools, its objects, and ways to get it. The writing classified kinds of Islamic Mysticism too into three types, Tasawuf Akhlaki, Tasawnf Amali, and Tasawuf Falsafi. Each type has the certain character. In the end, it will be explained how to know the validity of Sufism.
\end{abstract}

Kata kunci: Filosof, Sufi, Neo-Platonisme, Gnostisisme, Budhisme

\section{Pendahuluan}

Sejarah umat manusia mencatat bahwa segala amal dan usaha di dalam kehidupan adalah dorongan dari fikiran dan batin. Di dalam batin terletak pertimbangan antara yang buruk dan baik, cantik dan jelek. Apakah kebatinan itu? Inilah yang senantiasa menjadi pertanyaan dan penyelidikan dari ahli fikir sejak dunia berkembang sampai sekarang. Demi mencari diri dalam diri timbul bermacam-macam persoalan lain, dan sumber segala soal itu adalah soal tentang Yang Ada. ${ }^{1}$

Ahli filsafat menamainya Ontology atau metafisika, maka terbagi dualah manusia-manusia utama di dalam mencari Yang Ada itu. Satu jalan dengan fikiran dan satu lagi dengan jalan perasaan. Yang pertama itulah ahli Filsafat dan yang kedua inilah ahli Tasawuf, ${ }^{2}$ dan oleh kaum Orientalis Barat disebut sufisme. Kata sufisme dalam istilah Orientalis Barat khusus dipakai untuk mistisisme Islam. Sufisme tidak dipakai untuk mistisisme yang terdapat dalam agama-agama lain. ${ }^{3}$

Tasawuf sebagai salah satu tipe mistisisme, dalam bahasa Inggris disebut Sufism. ${ }^{4}$ Sebagaimana halnya dengan mistisisme di luar agama Islam, mempunyai tujuan memperoleh hubungan langsung dan disadari dengan Tuhan, sehingga disadari benar bahwa seseorang berada didekat Tuhan, ini merupakan suatu ilmu pengetahuan. ${ }^{5}$

Epistemologi adalah cara mendapatkan pengetahuan yang benar ${ }^{6}$ sebab di dalamnya terdapat pembahasan mengenai bagaimana cara mendapatkan pengetahuan, dalam hal ini adalah tentang ilmuilmu tasawuf. Uraian di bawah ini berusaha menelusuri pengertian tasawuf, asal-usul aliran tasawuf, sejarah kejadian dan objek ilmu-ilmu tasawuf, cara memperoleh ilmu-ilmu tasawuf dan apa ukuran kebenaran bagi ilmu-ilmu tasawuf.

\footnotetext{
${ }^{1}$ Hamka, Tasauf: Perkembangan dan Pemurniannya (Jakarta: Pustaka Panjimas, 1994), cet. 19, 9.

${ }^{2}$ Hamka, Tasauf, 9 .

${ }^{3}$ Harun Nasution, Falsafat dan Mistisisme Dalam Islam (Jakarta: Bulan Bintang, 1995), cet. 9, 56.

${ }^{4}$ A. Rivay Siregar, Tasawuf: Dari Sufisme Klasike ke Neo-Sufisme (Jakarta: RajaGrafindo Persada, 1999), cet. 1, 31.

${ }^{5}$ Harun Nasution, Falsafat dan Mistisisme, 56

${ }^{6}$ Jujun S. Suriasumantri, Filsafat Ilmu: Sebuah Pengantar Populer (Jakarta: Pustaka Sinar Harapan, 1996), cet. 10, 100.
} 


\section{Definisi Tasawuf}

Secara etimologi, kata ini berasal dari shûfí (صوفي) yang mengandung banyak padanan kata, seperti Abl al-Shuffah (أهل الصغة) yang berarti orang-orang miskin yang tak mempunyai apa-apa dan mereka tinggal di Mesjid Nabi; Shaff(صف) yakni shalat di shaf pertama; Shûfî (صو ئ) dari صاف dan صفي yaitu suci; dan Shuf (صف) kain yang dibuat dari bulu yaitu wol. ${ }^{7}$ Adapun padanannya dalam bahasa Yunani adalah Sophos yang berarti hikmat. Shufanah yaitu tumbuh-tumbuhan berbulu yang hidup di padang pasir. Hal ini dihubungkan dengan para Sufi yang memakai pakaian berbulu dan hidup dalam kesederhanaan seperti pohon Shufanah. ${ }^{8}$ Menurut sejarah, orang yang pertama kali memakai kata shûfî ini adalah seorang zâhid bernama Abu Hasyîm al-Kûfi di Irak (w.150 H). ${ }^{9}$

Adapun secara terminologi, definisi tasawuf ini telah dikemukakan oleh para Sufi sendiri, seperti;

1. Ma'ruf al-Karakhi: "Tasawnf adalab mengambil Hakikat dan berputus asa pada apa yang ada di tangan sesama makhluk."

2. Syamnun: "Tasawuf adalah bahwa engkau memiliki sesuatu dan tidak dimiliki oleh sesuatu."

3. Muhammad Ali al-Qassab : "Tasawnf adalah akblak yang mulia yang timbul pada mulia dari seorang yang mulia di tengah-tengah kaumnya yang mulia."11

4. $\quad$ Abu Said al-Harraz (w.268): "Seseorangyang hatinya dibersibkan Allah, sehingga penuh hatinya dengan Nûr Allah, yang termasuk di dalamnya lezatnya mengingat Allah."12

Jadi dapat disimpulkan dari beberapa definisi di atas, dapat diringkaskan sebagai berikut: Ilmu tasawuf adalah ilmu yang mempelajari usaha membersihkan diri, berjuang memerangi hawa nafsu, mencari jalan kesucian dengan ma'rifat menuju keabadian, saling mengingatkan antara manusia, serta berpegang teguh pada janji Allah dan mengikuti syari'at Rasulullah dalam mendekatkan diri dan mencapai keridaan-Nya.

\section{Asal-Usul Aliran Tasawuf}

Pada dasarnya, banyak teori yang menyebutkan tentang asal-usul kemunculan aliran tasawuf dalam Islam. Perbedaan teori ini disebabkan oleh banyak hal, diantaranya karena pengaruh Kristen, Neo-Platonisme, Gnostisime, Budhisme ${ }^{13}$ dan pengaruh ajaran Hindu ${ }^{14}$.

Demikian beberapa faham dan ajaran yang menurut teorinya mempengaruhi timbul dan munculnya sufisme di kalangan umat Islam. Kebenaran teori-teori tersebut sulit untuk dibuktikan, tetapi bagaimanapun, dengan atau tanpa pengaruh-pengaruh dari luar, sufisme bisa timbul dalam Islam. Di dalam al-Qur'an memang banyak ayat mengatakan bahwa manusia dekat sekali dengan Tuhan, di antaranya;

\footnotetext{
${ }^{7}$ Harun Nasution, Falsafat dan Mistisisme, 56-57. Lihat juga Martin Lings, What is Sufism?, terj. Akhmad, Membedah Tasawuf (Jakarta: Pedoman Ilmu Jaya, 1991), cet. 2, 39-40. Bandingkan Carl W.Ernst, The Shambhala Guide to Sufism, terj. Arif Anwar, Ajaran dan Amaliah Tasawuf; Sebuah Pengantar (Jogjakarta: Pusataka Sufi, 2003), cet. 1, 23.

${ }^{8}$ M.Yusran, Asmuni, Pertumbuhan dan Perkembangan Berfikir Dalam Islam (Surabaya: Al-Ikhlas, 1994), cet. 1, 130.

${ }^{9}$ Harun Nasuton, Falsafat dan Mistisisme, 56.

${ }^{10}$ Barmawi Umari, Sistematik Tasawnuf(Solo: Ramadhani, 1994), cet. 4, 14.

${ }^{11}$ Rosehan Anwar dan Mukhtar Solihin, Ilmu Tasawuf (Bandung: Pustaka Setia, 2000), cet. 1, 13.

${ }^{12}$ M. Laily Mansur, Tasawuf Islam: Menganal Aliran dan Ajaran (Banjarmasin: Lambung Mangkurat University Press, 1992), cet. $1,27$.

${ }^{13}$ Baca Reynold A. Nicholson, The Mystics of Islam, terj. Tim Penerjemah BA, Mistik Dalam Islam (Jakarta: Bumi Aksara, 1998), cet. 1, 8-15.

${ }^{14}$ M. Yusran Asmuni, Pertumbuban dan Perkembangan, 131.
} 


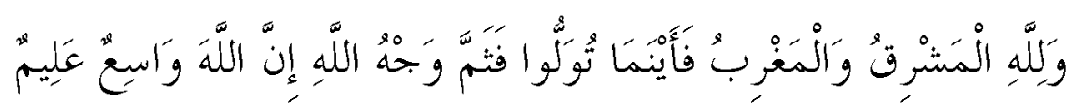

"Dan kepunyaan Allah-lah timur dan barat, Maka kemanapun kamu menghadap di situlah wajah Allah Sesunggubnya Allah Maha Luas (rahmat-Nya) lagi Maha mengetahui.” Q.S. al-Baqarah/ 2: 115.

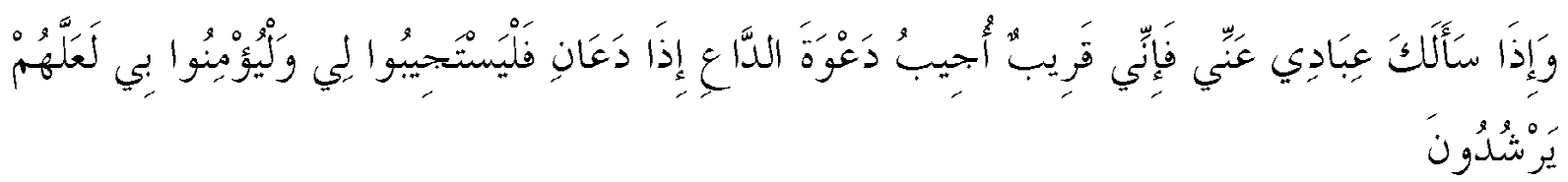

"Dan apabila hamba-hamba-Ku bertanya kepadamu tentang Aku, Maka (jawablab), bahwasanya aku adalab dekat. aku mengabulkan permohonan orang yang berdoa apabila ia memohon kepada-Ku, Maka bendaklah mereka itu memenubi (segala perintah-Ku) dan bendaklah mereka beriman kepada-Ku, agar mereka selalu berada dalam kebenaran.” Q.S. al-Baqarah/ 02: 186.

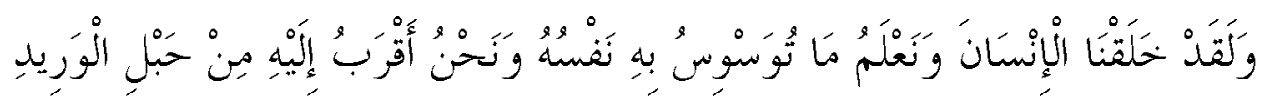

"Dan Sesunggubnya Kami telah menciptakan manusia dan mengetahui apa yang dibisik.kan oleh hatinya, dan Kami lebih dekat kepadanya daripada urat lehernya.” Q.S. Qaf/50: 16.

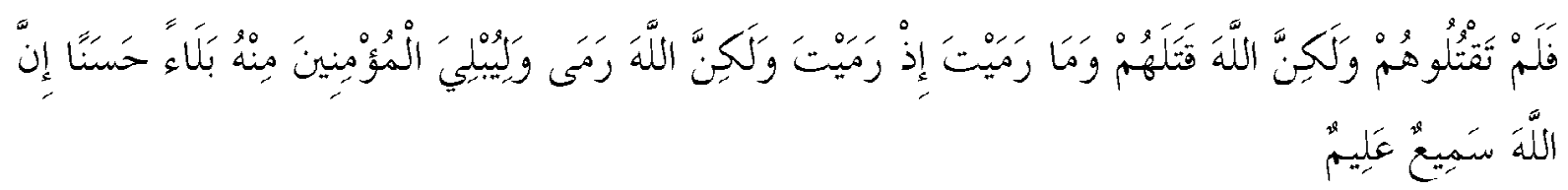

"Maka (yang sebenarnya) bukan kamu yang membunub mereka, akan tetapi Allablah yang membunub mereka, dan bukan kamu yang melempar ketika kamu melempar, tetapi Allah-lah yang melempar. (Allah berbuat demikian untuk membinasakan mereka) dan untuk memberi kemenangan kepada orang-orang mukmin, dengan kemenangan yang baik.Sesunggubnya Allah Maha mendengar lagi Maha mengetahui." Q.S. Al-Anfâl/08: 17.

Dan masih banyak lagi ayat lain yang menjelaskan tentang masalah kedekatan Tuhan. Pada dasarnya, hidup sufi sudah terdapat pada diri Rasulullah, sehari-hari ia hidup penuh dengan kesederhanaan, di samping menghabiskan waktunya dengan dakwah, mengajarkan ilmu kepada ummatnya, beribadah kepada Tuhan-Nya, dan melayani setiap orang yang datang kepada beliau. ${ }^{15}$ Praktik seperti ini kemudian dilakukan juga oleh para sahabatnya, tabi'in dan dikembangkan oleh para Sufi setelah masanya.

\section{Objek dan Cara Memperoleh Ilmu-Ilmu Tasawuf}

Adapun yang menjadi pengetahuan mistik (termasuk Tasawuf) ialah objek abstrak-supra-rasional, seperti alam gaib, termasuk Tuhan, malaikat, surga, neraka dan lain-lain, juga termasuk di dalamnya rasa seperti; cinta, bahagia, susah, yaqin dan sebagainya. Semua objek tersebut termasuk yang tidak dapat dipahami oleh rasio. ${ }^{16}$

\footnotetext{
${ }^{15}$ Abu Bakar Aceh, Pengantar Sejarah Sufi dan Tasawuf (Solo: Ramadhani, 1996), cet. 10, 41.

${ }^{16}$ Ahmad Tafsir, Filsafat Ilmu: Mengurai Ontologi, Epistemologi dan aksiologi Pengatabuan (Bandung: Remaja Rosdakarya, 2006), cet. 2, 118-119.
} 
Akal (rasio) dan indera merupakan dua alat pengetahuan. Pemujaan yang pertama melahirkan rasionalisme, sementara pemujaan yang kedua melahirkan sensualime, empirisisme, materialisme, dan positivisme. Jika yang pertama objeknya bersifat abstrak dan paradigmanya logis, yang kedua objeknya bersifat empiris dan paradigmanya adalah sains. Kedua paradigma ini menolak objek mistis yang supralogis dan non-empiris. Dua alat pengetahuan di atas, mau tidak mau, harus diakui telah memberikan porsi yang besar dalam kelahiran sains dan teknologi, namun ternyata tidak bisa berbuat apa-apa pada objek yang irrasional, metafisis, dan metainderawi. ${ }^{17}$

Bagaimana memperoleh ilmu-ilmu tasawuf? Pengetahuan tentang ilmu tasawuf itu tidak diperoleh melalui panca indera dan tidak juga menggunakan akal rasional, pengetahuan tasawuf diperoleh melalui rasa. Adapun Immanuel Kant berpendapat melalui moral, yang lain mengatakan melalui intuisi, ada juga yang mengatakan melalui insight, sementara al-Ghazali mengatakan melalui dhamir atau qalbu. ${ }^{18}$ Lalu bagaimana pengetahuan itu diperoleh? Untuk menjawab hal tersebut, perlu dijelaskan sumber pokok ajaran Islam yang memuat landasan praktek tasawuf, yaitu;

1. Al-Qur'an.

2. Al-Hadits.

3. Sejarah hidup Nabi dan Khulafâ al-Rasyidîn serta sahabat Nabi yang lain.

4. Situasi Kemasyarakatan.

5. Aliran-aliran kalam. ${ }^{19}$

Selanjutnya akan dikemukakan epistemologi tasawuf, bagaimana memperoleh pengetahuan tasawuf yang terbagi menjadi tiga macam, yaitu Tasawuf Akhlaki, Tasawuf Amali dan Tasawuf Falsafi.

\section{Tasawuf Akhlak}

Tujuan terpenting dari tasawuf adalah mendapatkan jalinan koneksi dengan Tuhan, sehingga merasa dan sadar berada di 'hadirat' Tuhan. Keberadaan di 'badirat'Tuhan itu dirasakan sebagai kenikmatan dan kebahagiaan yang hakiki. Satu-satunya jalan yang dapat menghantarkan seseorang ke hadirat Allah hanyalah dengan kesucian jiwa, untuk mencapai tingkat kesempurnaan dan kesucian jiwa memerlukan pendidikan dan latihan mental yang panjang. ${ }^{20}$

Dalam tasawuf akhlaki terdapat tahapan-tahapan yang harus dilalui yaitu sebagai berikut:

a. Takhalli merupakah langkah pertama yang harus ditempuh dengan usaha mengosongkan diri dari sikap ketergantungan terhadap kelazatan hidup duniawi, dengan jalan menjauhkan diri dari kemaksiatan dalam segala bentuknya dan berusaha melenyapkan dorongan hawa nafsu. $^{21}$

b. Tạalli merupakan langkah kedua dengan menghiasi diri dengan jalan membiasakan diri dengan sifat dan sikap serta perbuatan yang baik,berjalan sesuai dengan ketentuan agama baik yang bersifat lahir maupun bathin. ${ }^{22}$

c. Tajalli merupakan terungkapnya nur ghaib bagi hati. ${ }^{23}$

${ }^{17}$ Agus Effendi, “Tasawuf Sebagai Mazhab Epistemologi”, dalam Sukardi (ed.), Kuliah-Kuliab Tasawuf(Bandung: Pustaka Hidayah, 2000), cet. 1, 61 .

${ }^{18}$ Ahmad Tafsir, Filsafat Ilmu, 119.

${ }^{19}$ Baca Team Penyusun Proyek Pembinaan Perguruan Tinggi Islam IAIN Sumatera Utara, Pengantar Ilmu Tasawnf(Medan: Naspar Djaja, t.th.), 21-25

${ }^{20}$ Lihat Team Penyusun Proyek Pembinaan Perguruan Tinggi Islam IAIN Sumatera Utara, Pengantar Ilmu Tasawuf, 95-96.

${ }^{21}$ Baca Team Penyusun Proyek Pembinaan Perguruan Tinggi Islam IAIN Sumatera Utara, Pengantar Ilmu Tasawuf, 99.

${ }^{22}$ Baca Team Penyusun Proyek Pembinaan Perguruan Tinggi Islam IAIN Sumatera Utara, Pengantar Ilmu Tasawuf, 101.

${ }^{23}$ Baca Team Penyusun Proyek Pembinaan Perguruan Tinggi Islam IAIN Sumatera Utara, Pengantar Ilmu Tasawuf, 110. 


\section{Tasawuf Amali}

Hasrat untuk mendekatkan diri kepada Allah adalah tujuan pokok dari Sufi dan keinginan yang manusiawi, akan tetapi tidak semua orang bisa melakukannya, tidak tahu jalan yang ditempuh, dan tidak mengatahui bagaimana caranya untuk mendekatkan dirinya. Maka dibutuhkan orang yang dapat membantu dan memberi petunjuk ke arah tercapainya tujuan tersebut, yang disebut dengan guru. Dilihat dari tingkatan dalam komunitas ini terdapat beberapa istilah penting yang harus diketahui, yaitu sebagai berikut:

a. Murid, adalah orang yang mencari pengetahuan dan bimbingan dalam melaksanakan ibadahnya dengan memusatkan segala perhatian dan usahanya ke arah itu, melepas segala kemauannya dengan menggantungkan diri dan nasibnya kepada iradah Allah. Dalam dunia tasawuf, murid itu digolongkan menjadi tiga kelas yaitu;

1) Mubtadi atau pemula, yatu mereka yang baru mempelajari Syari'at.Jiwanya masih terikat pada kehidupan duniawi, kelas ini berlatih melakukaan amalan-amalan zhahir secara tetap dengan cara dan dalam waktu tertentu.

2) Mutawassith atau tingkat menengah, yaitu mereka yang sudah mempunyai pengetahuan yang cukup tentang Syari'at dan sudah mulai memasuki pengetahuan dan amalan yang bersifat bâthiniyah. Tahap ini adalah tahap belajar dan berlatih mensucikan bathin agar tercapai akhlak yang baik.

3) Muntabi adalah tingkat teratas, yaitu mereka yang telah matang ilmu Syari'at, sudah menjalani Thârikat dan mendalami ilmu bâthiniyah, sudah bebas dari perbuatan maksiat sehingga jiwanya bersih. Orang di tingkatan ini disebut ‘̂rif.

b. Syekh, adalah seorang pemimpin kelompok kerohanian, pengawas murid dalam segala kehidupannya, petunjuk jalan dan sewaktu-waktu dianggap sebagai perantara antara seorang murid dengan Tuhannya.

c. Wali dan Quthub adalah seorang yang telah sampai ke puncak kesucian bathin, memperoleh ilmu laduni yang tinggi sehingga tersingkap tabir rahasia-rahasia.

Apabila dilihat dari sudut amalan serta jenis ilmu yang dipelajari, maka terdapat beberapa istilah yang khas dalam dunia tasawuf, yaitu ilmu lahir dan ilmu bathin. Bahkan untuk memahami dan mengamalkan suatu amalam juga harus melalui aspek lahir dan aspek bathin. Kedua aspek itu terkandung dalam ilmu, yang mereka bagi kepada empat kelompok, yaitu;

a. Syariat, diartikan sebagai amalan-amalan lahir yang difardlukan dalam agama, atau mengikuti agama tuhan dan mengerjakan perintahnya dan menjauhi larangannya. ${ }^{24}$

b. Tarikat yakni mengamalkan agama dengan apik, teliti dan sungguh serta melatih diri dengan mengerjakan ibadah yang payah-payah dengan penuh kesabaran dan melapangkan hati dari kebimbangan untuk ibadah kepada Tuhan. ${ }^{25}$

c. Hakikat adalah sampainya maksud dan memandang Allah dengan terbukanya hijab dan ini jalan terakhir tujuan seseorang yang Thârikat (sâlik) yaitu mengenal Allah dengan terbukanya hijab dirinya hingga ia memandang Allah dengan mata hatinya. ${ }^{26}$

\footnotetext{
${ }^{24}$ Baca Muhammad Sarni al-Alabiy, Tuhfah al-Râghibîn fi Bayân Tharîqi al-Sâlikîn (Banjarmasin: TB Murni, t.th.), 9.

${ }^{25}$ Baca al-Alabiy, Tubfah al-Raghibîn, 10.

${ }^{26} \mathrm{Baca}$ al-Alabiy, Tuhfah al-Raghibin, 11.
} 
d. Ma'rifat adalah terhimpunnya tiga perkara di atas dengan pengenalan yang sebenarnya dengan Allah, melalui hati sanubari, pengetahuan itu sedemikian lengkap dan jelas sehingga jiwanya merasa satu dengan yang diketahuinya. ${ }^{27}$

Adapun terkait jalan atau cara mendekatkan diri kepada Allah, ada beberapa terma yang perlu diketahui, yaitu

a. Maqâmât

Untuk mencapai tujuan tasawuf seorang mubtadi harus menempuh jalan yang panjang dan berat, melakukaan bermacam usaha dan amal baik yang bersifat zahir maupun batin, dengan tahapan-tahapan tertentu yang disebut dengan istilah maqâm, dan semua itu dilalui dengan mijahadah, dan selalu sibuk dengan berbagai riyâdhah. ${ }^{28}$ Adapun tahap-tahap yang akan dilalui, sebagian sufi berbeda pendapat diantaranya, ialah; al-taubah, al-zuhud, alwara', al-faqr, al-shabr, al-tawakekal, dan al-ridha. ${ }^{29}$

b. Al-Ahwâl

Al-Ahwâl adalah situasi kejiwaan yang diperoleh seseorang sebagai kurnia Allah, bukan dari hasil usahanya. Datangnya kondisi mental tersebut tidak menentu, terkadang datang dan pergi berlangsung sangat cepat, sebagaimana dengan maqâm dalam jumlah dan formasi yang berbeda. Macam al-abwâl ini juga terdapat perbedaan di kalangan Sufi, tetapi yang terpenting dan populer adalah; al-murâqabah, al-khauf, ar-rajâ', al-syauq, al-uns, al-thama'ninah, al-musyâhadah, dan al-yaqîn. ${ }^{30}$

\section{Tasawuf Filsafat}

Konsepsi ahli tasawuf tentang Tuhan merupakan perkembangan lanjut dari pemikiran mutakallimin dan filosuf. Apabila pemikiran dan perenungan mutakallimin kelompok rasionalis menyebabkan posisi Tuhan sebagai sesuatu kenisykilan yang logis tanpa isi yang positif, maka kelompok tradisional menjadikan Tuhan sebagai penguasa "absolut" yang dapat berbuat sekehendaknya. Di sisi lain, para filosuf ingin menjembatani akidah Islam dengan filsafat, sehingga terpaksa harus "mempereteli" sebagian dari sifat-sifat Tuhan yang menjadikan Tuhan seakan-akan tidak punya aktifitas lagi. Untuk menjawab hal ini, maka kaum Sufi tampil dengan konsepsinya yang khas.

Dilihat dari sejarah perkembangan tasawuf yang panjang dan kompleks, ternyata sulit diformulasikan secara konsepsional pemikiran dan perenungan mereka tentang Tuhan. Namun secara garis besar, hal ini dapat dikelompokan menjadi tiga konsepsi tentang Tuhan, yaitu:

a. Konsepsi etika

b. Konsepsi estetika

c. Konsepsi kesatuan wujud

Masing-masing konsepsi, menurut mereka, secara langsung atau tidak langsung berakar dari al-Qur'an dan Sunnah.

\footnotetext{
${ }^{27}$ Baca al-Alabiy, Tuhfah al-Raghibîn, 7. Baca juga Team Penyusun Proyek pembinaan Perguruan Tinggi Islam IAIN Sumatera Utara, Pengantar Ilmu, 126-130.

${ }^{28}$ Abul Qâsim Abdul Karîm Hawazin al-Qusyairi al-Naisabûri, Al-Risalah al-Qusyairiyah fi Tlmi al-Tashwwnf, terj. Umar Faruq, Risalah Qisyairiyah Sumber Kajian Ilmu Tasawnf (Jakarta: Pustaka Amani, 1998), cet. 1, 57-58.

${ }^{29}$ Baca Harun Nasution, Falsafat dan Mistisisme, 62.

${ }^{30}$ Baca Harun Nasution,Falsafat dan Mistisisme, 63.
} 
Ada beberapa aliran-aliran yang berkembang dalam Tasawuf Falsafi, yaitu;

a. Al-Fana' dan Baqâ'

Fana secara harfiah berarti hilang, hancur, meninggal, dan baqa berarti terus hidup, selamanya. Dalam kaitan ini digunakan dengan preposisi al-fana 'an al-nafs maksudnya kosong dari segala sesuatu, melupakan atau tidak menyadari sesuatu, dan baqa bi al-nafs, sebaliknya berarti diisi dengan sesuatu, hidup bersama sesuatu, konsep ini ditimbulkan oleh Abu Yazid al-Bustami. ${ }^{31}$

b. Al-Ittihâd adalah kesatuan wujud, maksudnya dirinya merasa bersatu dengan Tuhan yang dicintai dan mencintai menjadi satu.

c. Al-Hulûl ialah faham bahwa mengambil tempat dalam tubuh manusia tertentu, yaitu manusia yang dapat melenyapkan sifat-sifat kemanusiaannya melalui fana, faham ini pertama kali dimunculkan oleh Husein Ibnu Mansur al-Hallaj.

d. Wabdatul Wujûd adalah faham bahwa wujud segala yang ada ini tergantung dengan wujud Tuhan, karenanya yang mempunyai wujud hakiki hanyalah Tuhan sedangkan yang lain tidak punya wujud, hanya satu wujud yaitu wujud Allah.

e. Al-Isyrâq yakni faham bahwa sumber segala sesuatu Yang Ada adalah cahaya yang mutlak atau Nûr al-Qâhir. Faham ini juga menyatakan bahwa alam ini diciptakan melalui penyinaran atau illuminasi. ${ }^{32}$

\section{Ukuran Kebenaran Ilmu-Ilmu Tasawuf}

Manusia adalah makhluk pencari kebenaran. Ada tiga jalan untuk mencari, menghampiri dan menemukan kebenaran, yaitu; sains (ilmu), filsafat dan agama. ${ }^{33}$ Kebenaran sains diukur dengan rasio dan bukti empiris. Bila secara teori, suatu pengetahuan sains tersebut rasional dan memiliki bukti empiris, maka ilmu tersebut benar. Adapun tolak ukur kebenaran pengetahuan filsafat adalah logis. Bila teori filsafat tersebut logis berarti teori itu benar. ${ }^{34}$ Semantara kebenaran ilmu-ilmu Tasawuf diukur dengan ukuran yang berasal dari Tuhan, maka ukurannya adalah teks Tuhan yang menyebutkan demikian. Tatkala Tuhan dalam al-Qur'an mengatakan bahwa surga dan neraka itu ada, maka teks itulah yang menjadi bukti bahwa pernyataan itu benar. ${ }^{35}$

\section{Penutup}

Dari bahasan di atas bahwa epistemology ilmu-ilmu Tasawuf terdiri dari objeknya yang abstrak supra-rasional, cara memperolehnya tidak melalui panca indera ataupun rasio melainkan dengan rasa, atau hati. Metode untuk memperoleh pengatahuan tentang tasawuf, ada dengan berfikir, ada yang melalui riadhah/ latihan, dan ada dari ilham ada dari pengalaman mereka masing-masing, dari itu menghasilkan ilmu-ilmu Tasawuf dan satu sama lain terdapat perbedaan pada masing-masing aliran, sedangkan ukuran kebenaran ilmu-ilmu Tasawuf adalah teks al-Qur'an dan as-Sunnah, di samping pola kehidupan para sahabat.

\footnotetext{
${ }^{31}$ Muhammad Abdul Haq Anshâri, Sufism and Shari'ab: A Study of Shaikh Ahmad Sirbindi's effort to Reform Sufism, terj. Ahmad Nashir Budiman, Antara Sufismedan Syari'ah (Jakarta: Rajawali Pers, 1990), cet. 1, 42-43.

${ }^{32}$ Baca Team Penyusun Proyek Pembinaan Perguruan Tinggi Islam IAIN Sumatera Utara, Pengantar Ilmu Tasawuf, 158168.

${ }^{33}$ Endang Saifuddin Anshari, Ilmu, Filsafat dan Agama (Surabaya: Bina Ilmu,1987), cet. 7, 171.

${ }^{34}$ Logis berarti masuk akal,logis dalam filsafat dapat berarti rasional atau supra-rasional.

${ }^{35}$ Endang Saifuddin Anshari, Ilmu, Filsafat, 121.
} 


\section{DAFTAR PUSTAKA}

Aceh, Abu Bakar. Pengantar Sejarah Sufi dan Tasawnf. Solo: Ramadhani. 1996.

Al-Alabiy, Muhammad Sarni. Tuhfah al-Râghibîn fî Bayâni Tharîqi al-Sâlikîn. Banjarmasin: TB Murni. t.th.

Ansari, Muhammad Abdul Haq. Sufism and Shariah: A Study of Shaikh Ahmad Sirbindi's effort to Reform Sufism. terj. Ahmad Nashir Budiman, Antara Sufisme dan Syariah. Jakarta: Rajawali, 1990.

Anshari, Endang Saifuddin. Ilmu, Filsafat dan Agama. Surabaya: Bina Ilmu. 1987.

Anwar, Rosihon dan Mukhtar Solihin. Ilmu Tasawuf. Bandung: Pustaka Setia. 2000.

Asmuni, M. Yusran. Pertumbuban dan Perkembangan Berfikir Dalam Islam. Surabaya: Al-Ikhlas. 1994.

Effendi, Agus. “Tasawuf Sebagai Mazhab Epistemologi”. dalam Sukardi (ed.), Kuliah-Kuliah Tasawuf. Bandung: Pustaka Hidayah. 2000.

Ernst, Carl W. The Shambhala Guide to Sufism, alih bahasa, Arif Anwar, Ajaran dan amaliah Tasawuf; Sebuah Pengantar. Jogjakarta: Pusataka Sufi. 2003.

Hamka. Tasauf, Perkembangan dan Pemurniannya. Jakarta: Pustaka Panjimas. 1994.

Lings, Martin. What is Sufism?. terj. Akhmad. Membedah Tasawuf. Jakarta: Pedoman Ilmu Jaya. 1991.

Mansur, M. Laily. Tasawuf Islam: Mengenal Aliran dan Ajaran. Banjarmasin: Lambung Mangkurat University Press. 1992.

Nasution, Harun. Falsafat dan Mistisisme dalam Islam. Jakarta: Bulan Bintang. 1995.

Nicholson, Reynold A. The Mystics of Islam. terj. Tim Penerjemah BA. Mistik Dalam Islam. Jakarta: Bumi Aksara. 1998.

Al-Qusyairi, Abul Qâsim Abdul Karîm Hawâzin al-Naisabûri. Al-Risâlah al-Qusyairiyah fì Tlmi alTashawwuf. terj. Umar Faruq. Risalah Qusyairiyah: Sumber Kajian Ilmu Tasawuf. Jakarta: Pustaka Amani. 1998.

Siregar, A. Rivay. Tasawuf: Dari Sufisme Klasik ke Neo-Sufisme. Jakarta: Raja Grafindo Persada. 1999.

Suriasumantri, Jujun S. Filsafat Ilmu: Sebuah Pengantar Populer. Jakarta: Pustaka Sinar Harapan. 1996.

Tafsir, Ahmad. Filsafat Ilmu: Mengurai Ontologi, Epistemologi dan Aksiologi Pengetahuan. Bandung: Remaja Rosdakarya. 2006.

Team Punyusun Proyek Pembinaan Perguruan Tinggi Agama IAIN Sumatera Utara. Pengantar Ilmu Tasawnf. Medan: Naspar Djaja. t.th.

Umari, Barmawi. Sistematik Tasawnuf. Solo: Ramadhani. 1994. 